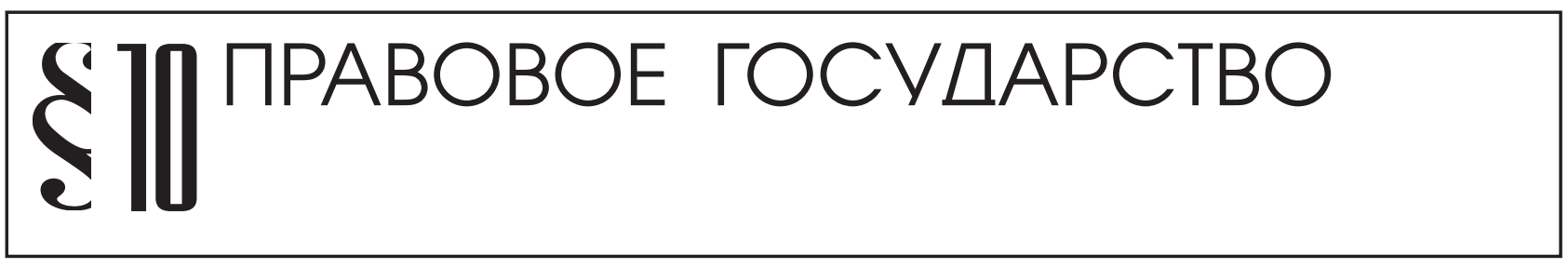

Соколов Т.В.

\title{
СУЩНОСТЬ КОНСТИТУЦИОННОГО СУДОПРОИЗВОДСТВА В КОНТЕКСТЕ ДОКТРИНЫ СУДЕБНОГО ПРАВА ${ }^{1}$
}

\begin{abstract}
Аннотация: Статья посвящена рассмотрению вопроса сущности конституционного судебного процесса (конституционного судопроизводства, конституционного правосудия). Имеющиеся в российской юридической литературе воззрения о том, что собой представляет конституционное судопроизводство, являются скорее дефинициями конституционного судебного процесса, нежели раскрытием сущности в её философско-методологическом понимании. Как известно, дефиниции обедняют сущность, а потому автор констатирует необходимость разработки нового методологического подхода к определению сущности конституционного судебного проиесса, одинаково применимого и к любым иным видам судопроизводства. Методологической основой проведенного исследования выступила доктрина судебного права - возрождающаяся в настоящее время общеправовая (универсальная) теория судебной власти и процессуального права. В статье формулирован оригинальньй методологический подход к определению сущнности процесса, который подход состоит в раскрытии сущности через последовательную характеристику природы, назначения, цели и задач данного вида судопроизводства. Опираясь на конституционное назначение судебной власти и характер материального права, применяемого в конституционном судопроизводстве для разрешения дел по существу, автор представляет основанные на предложенном подходе трактовки назначения, иели и задач конституционного судебного прочесса.
\end{abstract}

Review: The article is devoted to the essence of the constitutional judicial process (constitutional proceedings and constitutional justice). Views on constitutional proceedings existing in Russian legal literature are mostly concept definitions of the constitutional judicial proceedings than descriptions of the true essence of the constitutional proceedings in terms of philosophy and methodology. It is well known that definitions impoverish the essence and therefore the author sate the need for development of a new methodological approach to defining the essence of the constitutional judicial process. The methodological ground of this research is the doctrine of judicial law, i.e. the general (universal) legal theory of the judicial power and procedural law being restored at present moment. The author of the article offers an original methodological approach to defining the essence of the process. This approach involves a successive description of the nature, purpose, goals and tasks of this form of judicial proceedings. Based on the definition of the constitutional judicial law and the nature of the substantive law used in the constitutional proceedings, the author offers interpretations of the purpose, goal and tasks of the constitutional judicial process based on the aforesaid approach.

Ключевые слова: Конституционный Суд РФ, конституционный судебный процесс, конституционное судопроизводство, конституционное правосудие, доктрина судебного права, судебное право, природа процесса, назначение судопроизводства, иель прочесса, задачи правосудия.

Keywords: Constitutional Court of the Russian Federation, constitutional judicial process, constitutional proceedings, constitutional justice, doctrine of judicial law, judicial law, nature of the process, purpose of the judicial law, purpose of the process, tasks of justice.

Л юбая наука начинается с определения терминов. Юридические науки в данном вопросе не исключения: только «договорившись о

1 Статья подготовлена при финансовой поддержке Российского гуманитарного научного фонда в рамках проекта терминах» ученые-юристы смогут полноценно продуцировать научное знание. Особенно остро этот

проведения научных исследований № 12-33-01232 на тему «Формы взаимосвязи конституционного и уголовного судопроизводств в контексте доктрины судебного права». 
терминологический вопрос стоит для формируемых в настоящее время областей научного юридического знания. Введение в формулу и содержание научной специальности 12.00.02 дисциплины «Конституционный судебный процесс» свидетельствует о том, что реальное осуществление конституционного судопроизводства, сложность дел, рассматриваемых Конституционным Судом РФ, конституционными и уставными судами субъектов РФ, предполагает появление новых проблем процессуального характера, требующих научного осмысления и разрешения. ${ }^{2}$

Кроме того, это свидетельствует как о научном признании важности и ценности осуществляемой конституционными судами деятельности, так и о тех важных задачах, которые стоят перед юридической наукой и заключаются в доктринальном и, прежде всего, процессуально-правовом осмыслении феномена конституционного правосудия.

Одним из отправных вопросов процессуального осмысления конституционного судопроизводства является раскрытие его сущности. Сущность судопроизводства предопределяет содержание институтов конституционного судебного процесса, а потому её раскрытие составляет самостоятельную задачи науки конституционного правосудия.

Решая данную задачу, важно определить методологию проводимого исследования. Поскольку конституционное судопроизводство есть деятельность судебная, пригодной методологией видится теория, объясняющая смысл процессуальных явлений в праве как таковых, а такой теорией представляется доктрина судебного права - возрождающаяся в настоящее время универсальная (общеправовая) теория судебной власти и процессуального права, обладающая междисциплинарным масштабом в пределах четырех видов судопроизводства. Данная теория, строя «мостик» между концептом судебной власти и процессуально-правовыми институтами, может построить целостную и системную теорию российского правосудия.

Обращаясь к внешним характеристикам судопроизводства, нельзя не заметить, что устоявшееся формально-догматическое определение исследуемого нами явления, отсутствует. Так, Энциклопедический словарь процессуального права определяет судопро-

${ }^{2}$ Власенко Н.A. О номенклатуре специальностей научных работников в области юриспруденции // Журнал российского права. - 2010. - № 7. - С. 98-109. изводство как производство и разрешение дела судом, одно из средств осуществления судебной власти. ${ }^{3}$

Определение судопроизводства «в чистом (рафинированном) виде» содержит, пожалуй, Федеральный закон «О государственной судебно-экспертной деятельности», статья 9 которого определяет судопроизводство как регулируемую процессуальным законодательством Российской Федерации деятельность суда или судьи в ходе судебного разбирательства гражданских, административных и уголовных дел, а также деятельность органа дознания, лица, производящего дознание, следователя или прокурора при возбуждении уголовного дела, проведении дознания и предварительного следствия. ${ }^{4}$ Видно, что данное понятие является собирательным и описывает круг субъектов и отчасти стадии уголовного процесса, а потому не может претендовать на универсальный и исчерпывающий характер.

Судопроизводство в литературе также определяется и как порядок рассмотрения и разрешения судами определенных категорий дел (А.Н. Власенко, ${ }^{5}$ В.П. Кашепов, А.А. Гравина и О.А. Макарова, ${ }^{6}$ В.В. Маклаков, ${ }^{7}$ С.Э. Несмеянова ${ }^{8}$ ). В литературе

${ }^{3}$ Судопроизводство // Процессуальное право: Энциклопедический словарь / Под ред. Т.Г. Морщаковой, П.А. Лупинской, Т.Е. Абовой, Н.Г. Салищевой. - М.: Норма, 2003. - С. 555.

${ }^{4}$ Федеральный закон от 31 мая 2001 года № 73-Ф3 «О государственной судебно-экспертной деятельности в Российской Федерации» // Собрание законодательства Российской Федерации. - 2001. - № 23 (4 июня). - Ст. 2291.

5 Власенко Н.А., Власенко А.Н. Судебная власть и судебная деятельность в Российской Федерации: Краткий курс лекций. - М.: Российская академия правосудия, 2005. - С. 37-38; Власенко А.Н. Соотношение понятий: «судебная власть», «судебная деятельность», «правосудие» и «судопроизводство» // Конституционные основы судебной власти: Материалы Всероссийской науч. конф. (Москва, Российская академия правосудия, 23 октября 2003 г.) / Под общ. ред. В.В. Ершова. - М.: Российская академия правосудия, 2004. - С. 19.

${ }^{6}$ Гравина А.А., Кашепов В.П., Макарова О.А. Конституционные принципы судебной власти Российской Федерации: Монография / Отв. ред. В.П. Кашепов. - М.: Юриспруденция, 2011. - С. 190.

${ }^{7}$ Конституционное (государственное) право зарубежных стран: В 4 т. - Т. 1-2. Часть общая / Отв. ред. Б.А. Страшун. - М.: Норма, 2000. - С. 671 (автор параграфа 1 главы Х-В.В. Маклаков).

${ }^{8}$ Несмеянова С.Э. 1) К вопросу об инстанционности конституционного судопроизводства в России // Конституционное право: восточноевропейское обозрение. - 2002. - № 4 (41). - С. 88; 2) Конституционный судебный процесс в России: Учебное пособие. - М.: РИОР; ИНФРА-М, 2012. - С. 24. 


\section{Политика и общество 2 (110) • 2014}

по конституционному и уголовно-процессуальному праву понятие «процесс» (а потому и судопроизводство) определяется по-разному: как правоотношение, как исключительно деятельность, как процесс, одновременно включающий в себя и деятельность, и правоотношения.

В науке конституционного судопроизводства первой позиции («судопроизводство - это правоотношение») придерживается Н.В. Витрук, предлагая понимать под конституционным судопроизводством урегулированную специальными процессуальными нормами совокупность процессуальных отношений между судом и другими участниками судопроизводства, опосредующих последовательность их процессуальных действий, направленных на достижение объективной истины при разрешении тех или иных категорий дел в соответствии с полномочиями конституционного суда. ${ }^{9}$

Вторая группа ученых полагает, что процесс (значит, и судопроизводство) - это исключительно деятельность. Такого подхода придерживаются Х.Б. Шейнин, называя судопроизводством осуществляемое в установленном законом порядке рассмотрение и разрешение дел, ${ }^{10}$ и Н.С. Райкова, которая характеризует конституционное судопроизводство как деятельность судебного органа конституционного контроля и лиц, участвующих в деле, по рассмотрению и разрешению дел, входящих в его компетенцию, в установленном законом порядке, состоящую из совершаемых в определенной последовательности и урегулированном законом порядке процессуальных действий. ${ }^{11}$ Называет конституционное судопроизводство процессуальной деятельностью и Г.А. Жилин. ${ }^{12}$ Сторонниками данного подхода можно признать Е.В. Корнукову, Ж.И. Овсепян и Е.В. Слепченко, поскольку они рассматривают конституционное судопроизводство как разновидность (форму) правосудия, а правосудие, в свою очередь, -

\footnotetext{
${ }^{9}$ Витрук Н.В. Конституционное правосудие. Судебно-конституционное право и процесс: Учебное пособие. - М.: Юристь, 2005. - С. 305.

${ }^{10}$ Комментарий к Конституции Российской Федерации / Под общ. ред. В.Д. Карповича. - М.: Изд-во, 2000. - С. 826 (автор комментария к статье 118 - Х.Б. Шейнин).

11 Райкова Н.С. Сущность конституционного судопроизводства // Журнал конституционного правосудия. - 2008. - № 5. - С. 9-15.

12 Жилин Г.А. Конституционное судопроизводство в механизме судебной защиты права // Журнал конституционного правосудия. - 2011. - № 4 (22). - С. 2-3.
}

как деятельность; ${ }^{13}$ следовательно, конституционное судопроизводство, по их мнению, является разновидностью правосудной (судебной) деятельности.

По мнению третьих, процесс одновременно включает в себя и деятельность, и правоотношения. В.А. Кряжков и Л.В. Лазарев понимают под конституционным судопроизводством совокупность проиессуальных действий и правоотношений (курсив мой. - T.С.), складывающихся между Конституционным Судом и другими субъектами при рассмотрении и разрешении дел, связанных с охраной Конституции. ${ }^{14}$ С.Э. Несмеянова понимает под конституционным судопроизводством одновременно и систему (совокупность) процессуальных действий по отправлению правосудия, и совокупность правоотношений, возникающих при рассмотрении и разрешении конституционных дел. ${ }^{15}$ Б.В. Россинский применительно к конституционному процессуальному праву, регламентирующему деятельность конституционных судов, пишет, что его предмет двуедин и включает в себя процессуальную деятельность федерального и региональных конституционных судов и складывающиеся в период и в результате судебной деятельности правоотношения. ${ }^{16}$

Также в литературе высказаны «оригинальные» позиции, увеличивающие число элементов процесса. Так, С.А. Татаринов под конституционным судопроизводством понимает урегулированный специальными конституционными процессуальными нормами порядок рассмотрения и разрешения конкретных дел, отнесенных к компетенции Конституционного Суда Российской Федерации, в ходе отправления конституционного правосудия или систему процессуаль-

13 Корнукова Е.В. Конституционные основы правосудия по уголовным делам: Автореф. дис. ... канд. юрид. наук / 12.00.02. - Саратов, 2003. - С. 9, 12-15; Овсепян Ж.И. Конституционное судебно-процессуальное право: у истоков отрасли права, науки и учебной дисциплины // Известия вузов. Правоведение. - 1999. - № 2. - С. 21; Слепченко Е.В. Конституционное судопроизводство: понятие и особенности // Юридический мир. - 2009. - № 2. - С. 17-23.

${ }^{14}$ Кряжсков В.А., Лазарев Л.В. Конституционная юстиция в Российской Федерации. - М.: Изд-во «Бек», 1998. - С. 146-147.

${ }^{15}$ Несмеянова С.Э. Конституционный судебный процесс в России: Учебное пособие. - М.: РИОР; ИНФРА-М, 2012. C. 24, 25.

${ }^{16}$ Россинский Б.В. К вопросу о конституционном судебном процессе как разновидности юридического процесса в Российской Федерации // Российская юстиция. - 2012. - № 6. - C. 50 . 
ных действий и правоотношений, складывающихся между участниками конституционного судебного процесса, направленных на обеспечение реализации Конституционным Судом форм судебного конституционного контроля. ${ }^{17}$

Таким образом, в определении сущности конституционного судопроизводства мы можем наблюдать наиярчайшую палитру мнений ученых. Однако, полагаем, что ни один из высказанных подходов адекватно и исчерпывающе все же не раскрывает природу судопроизводства конкретного вида.

Высказанные в литературе мнения, конечно, дают представление о том, чем является конституционный судебный процесс, но его нельзя признать исчерпывающим и полностью раскрывающим сущность этих видов процесса, поскольку аналогичные ответы (например, «это - правоотношение» или «это - деятельность») можно получить на вопросы о сущности обязательства в гражданском праве, гражданства в конституционном праве или же о природе миграционного учета.

Высказанные мнения в силу своей «однобокости» являются, скорее, дефинициями судопроизводства, а дефиниции, как известно, обедняют сущность. В связи с этим очевидна необходимость выработки нового подхода к определению сущности судопроизводства, что оправдывается целями настоящего исследования.

Определение сущности как конституционного судопроизводства, так и иных видов процесса, осуществляемое на методологической основе доктрины судебного права, должно основываться на философском понятии сущности как внутреннем содержании предмета, выражающемся в устойчивом единстве всех многообразных и противоречивых форм его бытия, ${ }^{18}$ как субстанциональном ядре самостоятельно существующего сущего, ${ }^{19}$ как неотъемлемом качестве явления (предмета), без которого его невозможно осмыслить. ${ }^{20}$ Поэ-

${ }^{17}$ Татаринов С.А. О юридической природе конституционного судопроизводства // Правовые проблемы укрепления российской государственности: Сборник статей. Ч. 23 / Под ред. В.Ф. Воловича. - Томск: Изд-во Том. ун-та, 2005. - С. 90.

18 Сущность // Новая философская энциклопедия: В 4 т. / Ин-т философии РАН; Нац. обществ.-науч. фонд; Предс. науч.-ред. совета акад. В.С. Степин. - М.: Мысль, 20002001. - URL: http://iph.ras.ru/elib/2902.html.

19 Философский энциклопедический словарь. - М.: ИНФРА-М, 2009. - С. 445.

${ }^{20}$ В методологии раскрытия сущности автор основывался на идеях диалектической логики, изложенных в том числе в ра- тому раскрытие сущности конкретного вида судопроизводства должно происходить через раскрытие таких глубинных и сущностных черт исследуемого объекта, которые четко и точно отграничивали бы его от иных других однопорядковых или однородных правовых явлений (например, других видов судопроизводства).

Как видится, в понятие сущности следует включать несколько элементов, которые в совокупности и объяснят, чем, для чего и как существует судопроизводство. Раскрытие сущности процесса на основе одного из ныне выделяемых его аспектов нам представляется уязвимым. Так, заявлений о том, что процесс, к примеру, есть правоотношение либо нечто иное, для решения вопроса явно недостаточно: такие утверждения являются скорее дефинициями процесса, нежели действительным раскрытием его сущности в вышеозначенном философском ее понимании. Нельзя идти и только по пути «процесс есть механизм реализации судебной власти»: безусловно, общая черта всех видов судопроизводства состоит в том, что они являются механизмами реализации судебной власти, однако это абсолютно не показывает специфику каждого из процессов, поскольку во всех отраслевых процессуальных науках одинаково ведется спор о характере устанавливаемой в этом процессе истине (материальная или формальная), на каждый из процессов по-разному влияют нормы материального права (сравним гражданско-правовой запрет на ссылку сторон в деле о займе на свидетельские показания и отсутствие аналогичных запретов в уголовно-процессуальном доказывании, вопросы право- и дееспособности в различных видах судопроизводства). Следовательно, необходимо использовать такие элементы, которые покажут как общие, так и специфические черты процессов. Таковыми нам представляются природа, назначение, цель и задачи различных видов судопроизводства. Именно в таком ансамбле мы сможем понять, чем, для чего и как существует процесс.

Раскрытие природы судопроизводства предполагает объяснение того, к числу каких правовых явлений оно относится, показывает его место в структуре правовой системы России и позволяет выявлять и описывать связи судопроизводства во внешней среде, т.е. межсистемные связи, в том числе между судопроизводствами различных видов. Для этого вновь обратимся к дискуссии о том, что же такое процесс. Как

боте В.И. Кириллова: Кириллов В.И. Логика познания сущности: Монография. - М.: Высшая школа, 1980. 


\section{Политика и общество 2 (110) • 2014}

представляется, справедливо утверждение о том, что судопроизводство (процесс) является правоотношением, содержание которого составляет деятельность, в силу следующего. По смыслу действующего законодательства, судопроизводство так или иначе представляет собой деятельность. Об этом свидетельствуют такие формулировки закона, как «судопроизводство осуществляется на основе состязательности и равноправия сторон» (статья 123, часть 3, Конституции Российской Федерации), «порядок уголовного судопроизводства» (часть 1 статьи 1 УПК), «судопроизводство ведется на русском языке» (часть 1 статьи 18 УПК). Порядок же этой деятельности не тождественен самой деятельности, а представляет собой ее нормативную модель. Поэтому утверждения ряда авторов о судопроизводстве как порядке рассмотрения и разрешения судами определенных категорий дел не должны касаться судопроизводства, поскольку они фактически определяют содержание предмета процессуального права, а не практику его применения.

Особенностью судопроизводства по сравнению с иными видами юридической деятельности, в том числе юридической, является то, что оно регламентируется только правом и существует исключительно в правовой форме. ${ }^{21}$ Судопроизводство любого вида начинается с юридического факта - действия его участника, предусмотренного нормой процессуального права (например, в уголовном судопроизводстве - с подачи сообщения о преступлении, а в конституционном - подачи (внесения) обращения в конституционный суд). После подачи соответствующего обращения лицо, его подавшее, имеет право на его разрешение соответствующим органом, в чьей компетенции находится рассмотрение обращений такого рода, в установленный законом срок, а у этого органа возникает обязанность рассмотреть данное обращение, принять по нему решение и уведомить о принятом решении заявителя (см. статьи 141-148 УПК, статьи 37-41 Закона о Конституционном Суде). Аналогичным образом происходит дальнейшее развитие судопроизводства.

\footnotetext{
${ }^{21}$ Иную позицию в данном вопросе занимает А.Д. Бойков, допуская в порядке исключения существование уголовно-процессуальных отношений вне правовой формы (Бойков А.Д. К изучению эффективности уголовно-процессуального закона // Эффективность применения уголовного закона. - М., 1973. С. 164). С такой точкой зрения все же согласиться нельзя, поскольку процесс (судопроизводство, правосудие) порождены правом, предназначены для его применения и охраняются им.
}

Таким образом, участники судопроизводства состоят в регулируемых правом отношениях, т.е. в правовых отношениях, или правоотношениях. Закономерно возникает вопрос о соотношении правоотношения и деятельности, а именно - входит ли деятельность в состав правоотношения (если да, то в каком качестве, а если нет, то как они соотносятся). В теории права и в отраслевых процессуальных науках вопрос о форме и содержании, предмете и объекте правоотношения, как известно, является дискуссионным. Ряд авторов - Ю.К. Толстой, Р.О. Халфина, В.К. Бабаев, М.С. Строгович, Б.А. Галкин, М.С. Саликов и др. - содержанием правоотношения считают субъективные права и субъективные юридические обязанности; другие - Ю.И. Гревцов, М.М. Агарков, Л.Д. Кокорев, Р.Д. Рахунов, В.П. Божьев и др. - конкретные действия субъектов правоотношения; третьи же- С.С. Алексеев, М.А. Гурвич, И.В. Федоров, Л.А. Чеговадзе, Е.Г. Лукьянова - наряду с юридическим содержанием (субъективными правами и обязанностями) выделяют его материальное содержание - фактическое поведение участников. ${ }^{22}$ П.С. Элькинд и Т.В. Свистунова дифференцировали поведение участников на возможное, которое составляет содержание правоотношения в статике, и на действительное - для отношений в динамике. ${ }^{23}$

Применительно к процессуальным правоотношениям данный вопрос должен иметь одно решение, которое видится следующим. В судопроизводстве важно видеть прежде всего реальное положение вещей, т.е. фактически совершенные действия или факты. Именно по реально совершившимся действиям

\footnotetext{
22 Подробнее об этой дискуссии см.: Божьев В.П. Уголовно-процессуальные правоотношения. - М.: Юридическая литература, 1975. - С. 140-151; Лукьянова Е.Г. Теория процессуального права. - 2-е изд., перераб. - М.: Норма, 2004. C. 204; Теория государства и права: Курс лекций / Под ред. Н.И. Матузова и А.В. Малько. - М.: Юристь, 1997. С. 90-91, 112-138; Саликов М.С. Конституционный судебный процесс в системе российского права // Журнал российского права. - 2003. - № 11. - С. 128; Ткаченко Ю.Г. Методологические вопросы теории правоотношений: Монография. - М.: Юридическая литература, 1980. - С. 130-131; Толстой Ю.К. К теории правоотношений: Монография. - Л.: Изд-во ЛГУ, 1959. - С. 48-66. Халфина Р.О. Общее учение о правоотношении. - М.: Юридическая литература, 1974. - С. 79-98; Чеговадзе Л.А. Структура и состояние гражданского правоотношения: Монография. - М.: Статут, 2004. - С. 32-57.

${ }^{23}$ Свистунова Т.В. Нормы уголовно-процессуального права и правоотношения: Автореф. дис. ... канд. юрид. наук. - Л., 1969. - С. 9.
} 
участников судопроизводства, а не по гипотетически возможным, оценивается законность проведения судопроизводства по конкретному уголовному или конституционному делу. Поэтому при рассмотрении сути судопроизводства на первое место встают процессуальные действия его участников, составляющие в совокупности их поведение, и именно их следует считать содержанием правоотношения. Права и обязанности участников судопроизводства составляют внешнюю форму правоотношения.

Подтверждение истинности вывода о сущности процесса как правоотношения находим в понятии правоотношения как урегулированного нормами права общественного отношения, содержанием которого является поведение (совокупность действий, их деятельность) его участников, а формой - их права и обязанности. ${ }^{24}$

Ошибочность второго подхода («процесс как деятельность») усматривается в том, что остается неясным, является ли та деятельность, которую предлагается именовать судопроизводством, регламентированной правом, если да, то каким. Такая неясность лишает определение четкости, поскольку судопроизводство всегда регламентировано правом, будучи им же и порождено, что не только признается, но и всегда подчеркивается всеми без исключения процессуалистами.

Третий подход («процесс - есть и деятельность, u правоотношение») создает впечатление, будто в рамках судопроизводства одновременно существуют и правоотношения, т.е. деятельность, урегулированная правом, и деятельность, которая такого качества не имеет. Однако представить такое явление в реаль-

24 Такая трактовка правоотношения разработана и признана в теории права. См.: Общая теория государства и права: Академический курс: В 2 т. / Под ред. проф. Н.М. Марченко. Т. 2. Теория права. - М.: Зерцало, 1998. C. 270; Марченко М.Н. Теория государства и права: Учебник. - М.: Проспект, 2003. - С. 585; Теория государства и права: Учебник для юридических вузов / Под общ. ред. проф. А.С. Пиголкина. - М.: Городец, 2003. - С. 364.

Такой подход, между прочим, не опровергает истинности воззрений теоретиков права (в особенности цивилистического «происхождения») на содержание правоотношений как совокупность субъективных прав и юридических обязанностей. Многообразие и структурная сложность складывающихся общественных отношений открывает исследователю случаи, когда лицо, не предпринимая каких-либо значимых юридических действий, приобретает, изменяет или утрачивает права и обязанности, т.е. вступает в правоотношения или же перестает быть их субъектом. ности весьма затруднительно, поскольку вся процессуальная деятельность так или иначе урегулирована правом, а выявленный практикой пробел может быть устранен применением аналогии права или аналогии закона. Кроме того, может сложиться ложное представление о существовании в судопроизводстве деятельности, которая не регламентирована процессуальным правом. Понимание процесса (т.е. любого из судопроизводств) как правоотношения основывается на положениях теории права, а также соответствует отечественной процессуальной традиции. ${ }^{25}$

Таким образом, процесс по своей природе является сложным правоотношением, состоящим из ряда элементарных отношений, возникающих между отдельными его участниками. ${ }^{26}$

Следующими элементами сущности судопроизводства являются его назначение, цель и задачи. Учитывая тесную связь между этими телеологическими категориями, следует остановиться на нашем понимании и разграничении этих категорий.

Как и по многим другим вопросам юридической науки, точки зрения ученых в данном вопросе разделились: одни юристы не видят разницы между целями, задачами и назначением судопроизводства, считая их синонимами; другие же различают их, вкладывая в содержание цели и задач судопроизводства разные юридические смыслы. Причина существования таких противоречивых мнений, как видится, кроется в отсутствии определенности по данному вопросу в философии и психологии, где цель определяется как совокупность частных задач, а задача - как цель на промежуточном этапе деятельности. ${ }^{27}$ Кроме того,

${ }^{25}$ См.: Гольмстен А.Х. Учебник русского гражданского судопроизводства / Под ред. и с предисл. М.К. Треушникова и Ю.А. Поповой. - Краснодар: Изд-во КубГАУ, 2004. С. 15-24; Полянский Н.Н. Спор о юридической природе уголовного процесса // Очерки общей теории уголовного процесса. - М.: Право и Жизнь, 1927. - С. 95-110.

${ }^{26}$ Полагаем, что судопроизводство - это совокупность ряда элементарных отношений, строящихся по принципу «суд $\leftrightarrow$ участник процесса». Очевидным подтверждением этому является порядок задавания вопросов в судебном заедании: они задаются стороной адресату не напрямую, а с разрешения суда. Следовательно, для реализации своих прав участники судопроизводства обязаны прибегнуть к помощи суда, с которым они состоят в правоотношениях.

27 Подробнее см.: Мезинов Д.А. О соотношении понятий «цель» и «задача» в науке уголовного процесса // Вестник Томского государственного университета. - 2010. - № 340. - C. 129-131. 


\section{Политика и общество 2 (110) • 2014}

не дает четкости в этом вопросе и законодатель. Так, УПК в статье 6 говорит лишь о назначении уголовного судопроизводства, а Закон о Конституционном Суде в статье 3 - о целях, во исполнение которых Конституционный Суд Российской Федерации осуществляет свои полномочия. Между тем, отсутствие законодательного закрепления каких-либо из исследуемых телеологических категорий - как то цели и задачи уголовного процесса, назначение и задачи конституционного судопроизводства - вовсе не означает отсутствие данных категорий как таковых. Например, сам Конституционный Суд в своих решениях ссылается на назначение (вернее, предназначение, что, с нашей точки зрения, является синонимами) конституционного судопроизводства. ${ }^{28}$

Категории назначения, цели и задач образуют телеологию процесса, т.е. устанавливают систему результатов, к достижению которых должен стремиться процесс. Между тем не все такие результаты находятся в одной плоскости. Деятельность суда в различных видах судопроизводства насколько разнообразна, что перед разными процессами ставятся ориентиры, несопоставимые просто в силу их природы: нельзя «ставить в одну линию» наказание преступников судами общей юрисдикции с содействием арбитражных судов становлению и развитию партнерских деловых отношений, формированию обычаев и этики делового оборота, либо признание нормы неконституционной Конституционным Судом с установлением объективной истины судами в гражданском, административном или уголовном процессах. Данные установки различны по своему масштабу, средствам и последствиям достижения. Однако между ними можно найти «общий знаменатель» на основе и в рамках доктрины судебного права. Трактовки назначения, цели и задач процесса должны быть универсальными - равно применимыми во всех видах судопроизводства. Причем эти телеологические установки должны быть ориентиром деятельности исключительно суда, поскольку именно он

${ }^{28}$ См. напр., Постановление Конституционного Суда Российской Федерации от 14 июля 2005 года № 9-П, определения Конституционного Суда Российской Федерации от 8 января 1998 года № 34-О, от 11 марта 1999 года № 10-О, от 10 ноября 2002 года № 270-О, от 25 декабря 2003 года № 454-О, от 27 декабря 2005 года № 467-О, от 13 октября 2009 года № 1274-О-О, от 17 ноября 2009 года № 1545-О-О, от 8 апреля 2010 года № 451-О-О и № 452-О-О, от 30 сентября 2010 года № 1237-О-О и № 1238-О-О, от 17 января 2012 года № 148-О-О, от 7 февраля 2012 года № 276-О-О и др. (а не стороны и даже не свидетели и понятые) и только он ответственен за результат процесса - итоговое решение по существу дела. Стороны имеют в процессе свои собственные противоречащие друг другу интересы, а перед процессом может быть поставлена только одна, причем внутренне непротиворечивая, телеологическая установка.

С позиций доктрины судебного права назначение, цель и задачи судопроизводства представляются разными правовыми категориями, поскольку обладают различным содержанием. Обратное - смешение, признание каких-либо из этих категорий синонимами - просто приводило бы к исключению из процессуального оборота науки одного из «прижившийся» терминов, что нельзя признать оправданным при активном использовании в теории и судебной практике каждого из них. ${ }^{29}$

Назначение процесса должно определяться исходя из философского и лексического значения термина «назначение», т.е. отвечать на вопрос «для чего сущуеcтвует этот вид судопроизводства?», что предполагает раскрытие той роли, которую конкретное судопроизводство играет в обществе и государстве. Поэтому при определении назначения судопроизводства следует учитывать как природу судебной власти, так и специфику норм материального права, применяемого для разрешения соответствующего судебного дела по существу. Поскольку в силу статьи 18 Конституции судебная власть призвана защищать права и свободы человека и гражданина, то судопроизводство, как механизм её реализации, должно быть призвано осуществлять эту защиту в соответствующих сферах материально-правовых отношений.

Такой подход обеспечивает связь процесса с институтом судебной власти, поскольку судопроизводство является механизмом реализации судебной власти, в силу чего природа судебной власти на наш взгляд обеспечивает справедливость порядка разрешения дела. Кроме того, такой подход предотвращает отрыв процесса от того материально-правового субстрата, на котором он «взращен». Справедливость является если не основополагающей, то одной из самых существенных характеристик судебной власти, поскольку требова-

\footnotetext{
${ }^{29}$ К вопросу методологии определения сущности судопроизводства, правда на примере уголовного процесса, мы обращались и ранее. См.: Соколов T.B. К вопросу о сущности уголовного процесса в контексте доктрины судебного права // Российский судья. - 2013. - № 6. - С. 22-25.
} 
ние процессуальной справедливости - есть международный стандарт, закрепленный статьей 10 Всеобщей декларации прав человека, пунктом 1 статьи 14 Международного пакта о гражданских и политических правах, пунктом 1 статьи 6 Конвенции о защите прав человека и основных свобод.

Следовательно, назначение судопроизводства в общем виде видится в реализации судом в условиях справедливого процессуального порядка норм материального права и, соответственно, в достижении целей материального права в конкретном правоотношении, ставшем предметом справедливого судебного разбирательства. Поэтому назначение судопроизводства, с одной стороны, предопределяет полномочия суда в конкретном виде судопроизводства, а с другой - пронизывает все институты, входящие в соответствующую отрасль процессуального права, и отвечает за их содержание.

Назначение судопроизводства выступает тем элементом, при помощи которого различаются виды судопроизводства. Между тем, назначения различных судопроизводств должны быть взаимосвязаны и соотноситься так, чтобы один процесс не выполнял функции другого процесса и (или) не осуществлял полномочия суда, которые принадлежат суду в судопроизводстве иного вида. В силу этого категория назначения судопроизводства может служить критерием, ориентиром для определения «места жительства» вновь вводимого процессуального института, для разграничения видов судопроизводства как таковых и при распределении подведомственности и подсудности дел между судами различной юрисдикции.

Прочтение Закона о Конституционном Суде не дает оснований утверждать о существовании категории назначения судопроизводства. Данный Закон содержит лишь одну телеологическую норму - статью 3, гласящую: «В целях защиты основ конституционного строя, основных прав и свобод человека и гражданина, обеспечения верховенства и прямого действия Конституции Российской Федерации на всей территории Российской Федерации Конституционный Суд Российской Федерации...».

Мнения ученых по вопросу назначения конституционного судопроизводства так или иначе воспроизводят статью 3 Закона о Конституционном Суде, ${ }^{30}$ од-

${ }^{30}$ Витрук Н.В. Цель, задачи и функции конституционного правосудия в государствах новой демократии // Конституционное правосудие: Вестник Конференции органов конститу- нако с позиций доктрины судебного права ответ на интересующий нас вопрос может отличаться от уже высказанных в науке.

Цели защиты основ конституционного строя, основных прав и свобод человека и гражданина, обеспечения верховенства и прямого действия Конституции на всей территории Российской Федерации равным образом стоят практически перед всеми видами судопроизводства, не только конституционным, поэтому в данном вопросе требуется следующее уточнение. Поскольку назначение конституционного судопроизводства должно пронизывать все конституционно-процессуальные институты, то оно должно определяться на основе конкретных полномочий Конституционного Суда, реализуемых если не во всех, то в подавляющем большинстве процессуальных производств, составляющих ядро конституционного судопроизводства. В конституционном судопроизводстве применяемым для разрешения по существу «материальным правом» является «чистое конституционное право» - нормы, содержащиеся в Конституции Российской Федерации, а для регионального конституционного правосудия - конституционно-правовые нормы, входящие в конституции (уставы) субъектов Российской Федерации. В силу этого основная масса полномочий Конституционного Суда связана с осуществлением контроля конституционности каких-либо нормативных положений нормоконтролем, который составляет «сердцевину», «ядро» современного конституционного судопроизводства. Производства по нормоконтролю в конституционном судопроизводстве между собой различаются инициаторами и поводами возбуждения конституционного судопроизводства и объектами (законы в формально-юридическом смысле, ряд подзаконных нормативных правовых актов, нормативные договоры, не вступившие в силу международные договоры Российской Федерации и т.п.), однако в сущностных своих характеристиках он остается не-

ционного контроля стран новой демократии. - 2002. - № 2 (16). - URL: www.concourt.am/armenian/con_right/2.16-2002/ vitruk.htm; Гаджиев Г.А. Цели, задачи и предназначение Конституционного Суда Российской Федерации // Журнал конституционного правосудия. - 2008. - № 1. - С. 10-17; № 2. - С. 8-12; Крусс В.И. Юбилей права: к вопросу о природе и назначении конституционной юстиции // Актуальные проблемы теории и практики конституционного судопроизводства: Сборник научных трудов. - Вып. VII. - Казань: ООО «Офсет-сервис», 2012. - С. 303-309. 


\section{Политика и общество 2 (110) • 2014}

изменным: Суд проверяет конституционность соответствующих подконтрольных ему правовых актов, занимающих подконституционный уровень, а при несоответствии - признает их неконституционными (данному механизму посвящена глава 3 настоящей работы). Осуществление же этой проверки происходит не само по себе, а отражает реализацию судебной власти, назначение которой, как следует из статьи 18 Конституции, является обеспечение и защиты конституционных прав и свобод человека и гражданина. Проецируя назначение судебной власти на ту сферу, в которой осуществляет свои полномочия Конституционный Суд, можно заключить, что конституционное судопроизводство имеет своим назначением защиту прав и свобод человека и гражданина от их нарушений на нормативном уровне правового регулирования. Если же назначением конституционного судопроизводства считать указанную в статье 3 Закона о Конституционном Суде «защиту прав и свобод» в собственном смысле, т.е. защиту от всяких нарушений, в том числе и фактических, то конституционное судопроизводство будет неотличимо от иных видов судопроизводства, ведь перед гражданским (статья 2 ГПК, статья 2 АПК), уголовным (статья 6 УПК) и даже административным судопроизводствами (статьи 1.2 и 24.1 КоАП) так или иначе стоит установка защиты прав и свобод каких-либо субъектов права. Между тем, как отмечалось ранее, именно назначение должно определять отличия между судопроизводствами. В этой связи Конституционный Суд следует рассматривать как суд законодателя, а предметом защиты - права и свободы человека и гражданина, нарушаемые нормативно.

Данной трактовке назначения отвечают практически все известные современному законодательству конституционно-судебные производства, включая дела о проверке соответствия Конституции Российской Федерации вопроса (вопросов) референдума и инициативы проведения референдума по предложенному вопросу (предложенным вопросам) референдума, ${ }^{31}$ за исключением, пожалуй, двух: дел о

\footnotetext{
${ }^{31}$ Разрешение Конституционным Судом этих вопросов предусмотрено соответственно частью 17 статьи 15 и частью 1 статьи 23 Федерального конституционного закона от 28 июня 2004 года № 5-ФКЗ «О референдуме Российской Федерации». Подробнее о природе этих производств см.: Вuтрук Н.B. 1) Производство в Конституционном Суде РФ по рассмотрению дела о соответствии Конституции РФ инициативы проведения референдума РФ по постановлен-
}

толковании Конституции и дел о даче заключения о соблюдении установленного порядка выдвижения обвинения Президента Российской Федерации в государственной измене или совершении иного тяжкого преступления. В первом случае Суд не устанавливает соответствие Конституции правовых актов меньшей юридической силы, а устраняет неопределенность в понимании конституционных положений, ${ }^{32}$ т.е. конституционного текста, следовательно, механизм работы Суда в этом производстве иной - не контрольный, а интерпретационный. Второй случай отличается объектом контроля: как следует из статьи 93 (часть 1) Конституции, им выступают не нормы права (действующие или «будущие», предлагаемые к введению), а фактические обстоятельства - конституционные процедуры формулирования и выдвижения Государственной Думой обвинения против Президента и его подтверждения Верховным Судом. Эти два конституционно-судебные производства имеют под собой конституционные основания и являются, пожалуй, тем исключением, которое только подтверждает правило.

При таком подходе указанные в Законе о Конституционном Суде защита прав и свобод, обеспечение верховенства и прямого действия Конституции на всей территории России выступает как те конституционные ценности, которые должны быть обеспечены законодателем. Конституционный контроль в данном случае выступает как гарантия претворения этих ценностей в законодательстве.

Цель процесса является телеологической установкой следующего уровня. Поскольку процесс есть особая форма применения судом материального права, цель судопроизводства должна отражать юридические характеристики судопроизводства. Правоприменение, как известно, предполагает три этапа - установление фактических обстоятельств дела,

ному вопросу (постановленным вопросам) референдума // Журнал конституционного правосудия. - 2010. - № 2 (14). С. 10-12; 2) Виды производств в Конституционном Суде РФ // Журнал конституционного правосудия. - 2009. - № 6 (12). - С. 11-17; Дагуев А.В. Виды производств и их особенности в конституционном судопроизводстве: Автореф. дис. ... канд. юрид. наук / 12.00.02. - М., 2009.

32 Часть вторая статьи 36 Закона о Конституционном Суде; постановления Конституционного Суда Российской Федерации от 31 октября 1995 года № 12-П, от 28 ноября 1995 года № 15-П, от 22 апреля 1996 года № 10-П, от 14 июля 1997 года № 12-П, от 16 июня 1998 года № 19-П, от 27 января 1999 года № 2-П, от 6 июля 1999 года № 10-П, от 11 июля 2000 года № 12-П. 
выбор нормы, подлежащей применению, и оформление правоприменительного решения. Следовательно, цель процесса состоит в достижении по делу судебной истины, т.е. в верном установлении судом фактических обстоятельств дела (объективной истины) и их правильной юридической квалификации (юридической истины). Истинность этой идеи подтверждается, как нам видится, в структуре судебного разбирательства, которая согласуется с указанными тремя этапами применения права.

Истина фактическая отражает те обстоятельства, к которым подлежит применению норма права. В традиционных видах судопроизводства этот вид истины лежит в плоскости фактических обстоятельств (например, состав преступления или административного правонарушения, обстоятельства заключения гражданско-правового или иного договора и т.д.). Фактическую истину в конституционном судопроизводстве составляет содержание проверяемых источников права, устанавливаемое с помощью разных видов толкования норм права.

Задачи процесса, завершая характеристику сущности процесса, отличны от цели, поскольку не связаны с применением права, а отражают иные, помимо правоприменительной, функции судебной власти. Представляется, что у судопроизводства как минимум две задачи (функции): профилактическая (предупредительная, превентивная) и воспитательная (культурная).

Профилактическая задача конституционного судопроизводства, на наш взгляд, состоит в предупреждении в будущем принятия законодательных актов с конституционными дефектами. Она реализуется посредством формулирования Конституционным Судом нормативных правовых позиций, которые в будущем связывают законодателя и предостерегают от принятия неконституционных актов.

Реализации воспитательной задачи обоих судопроизводств должен способствовать порядок рассмотрения и разрешения судами подведомственных им дел: необходимо, чтобы у присутствующих не возникало сомнений в тенденциозности, предвзятости, необъективности или пристрастности суда. Этому должно служить неукоснительное соблюдение судом норм процессуального права и принятие мер по устранению таких нарушений со стороны других участников судопроизводства.

Использование приведенных выше категорий позволяет определить судопроизводство как облеченную в форму процессуальных правоотношений деятельность суда, сторон и вовлекаемых в нее лиц по рассмотрению и разрешению на основе норм материального права соответствующих судебных дел. Стоящие перед судопроизводством телеологические установки отражают природу судебной власти и ориентируют суды на реализацию целей и норм материального права в конкретных правоотношениях, ставших предметом рассмотрения суда в конкретном деле.

\section{Библиография:}

1. Федеральный конституционный закон от 21 июля 1994 года № 1-ФКЗ «О Конституционном Суде Российской Федерации» (в редакции Федерального конституционного закона от 5 апреля 2013 года № 1-ФК3).

2. Божьев В.П. Уголовно-процессуальные правоотношения. - М.: Юридическая литература, 1975.

3. Бойков А.Д. К изучению эффективности уголовно-процессуального закона // Эффективность применения уголовного закона. - М., 1973. - С. 150-164.

4. Витрук Н.В. Виды производств в Конституционном Суде РФ // Журнал конституционного правосудия. - 2009. - № 6 (12). - С. 11-17.

5. Витрук Н.В. Конституционное правосудие. Судебно-конституционное право и процесс: Учебное пособие. - М.: Юристъ, 2005.

6. Витрук Н.В. Производство в Конституционном Суде РФ по рассмотрению дела о соответствии Конституции РФ инициативы проведения референдума РФ по постановленному вопросу (постановленным вопросам) референдума // Журнал конституционного правосудия. - 2010. - № 2 (14). - C. 10-12.

7. Витрук Н.В. Цель, задачи и функции конституционного правосудия в государствах новой демократии // Конституционное правосудие: Вестник Конференции органов конституционного контроля стран новой демократии. - 2002. - № 2 (16). - URL: www.concourt.am/armenian/ con_right/2.16-2002/vitruk.htm.

8. Власенко А.Н. Соотношение понятий: «судебная власть», «судебная деятельность», «правосудие» и «судопроизводство» // Конституционные основы судебной власти: Материалы Всероссийской науч. конф. (Москва, Россий- 


\section{Политика и общество 2 (110) • 2014}

ская академия правосудия, 23 октября 2003 г.)

/ Под общ. ред. В.В. Ершова. - М.: Российская академия правосудия, 2004. - С. 18-22.

9. Власенко Н.А. О номенклатуре специальностей научных работников в области юриспруденции // Журнал российского права. - 2010. - № 7. - С. 98-109.

10. Власенко Н.А., Власенко А.Н. Судебная власть и судебная деятельность в Российской Федерации: Краткий курс лекций. - М.: Российская академия правосудия, 2005.

11. Гаджиев Г.А. Цели, задачи и предназначение Конституционного Суда Российской Федерации // Журнал конституционного правосудия. - 2008. - № 1. - С. 10-17; № 2. - С. 8-12.

12. Гольмстен А.Х. Учебник русского гражданского судопроизводства / Под ред. и с предисл. М.К. Треушникова и Ю.А. Поповой. - Краснодар: Изд-во КубГАУ, 2004.

13. Гравина А.А., Кашепов В.П., Макарова О.А. Конституционные принципы судебной власти Российской Федерации: Монография / Отв. ред. В.П. Кашепов. - М.: Юриспруденция, 2011.

14. Дагуев А.В. Виды производств и их особенности в конституционном судопроизводстве: Автореф. дис. ... канд. юрид. наук / 12.00.02.

15. Жилин Г.А. Конституционное судопроизводство в механизме судебной защиты права // Журнал конституционного правосудия. - 2011. - № 4 (22). - С. 2-3.

16. Кириллов В.И. Логика познания сущности: Монография. - М.: Высшая школа, 1980.

17. Комментарий к Конституции Российской Федерации / Под общ. ред. В.Д. Карповича. - М.: Издво, 2000.

18. Конституционное (государственное) право зарубежных стран: В 4 т. - Т. 1-2. Часть общая / Отв. ред. Б.А. Страшун. - М.: Норма, 2000.

19. Корнукова Е.В. Конституционные основы правосудия по уголовным делам: Автореф. дис. ... канд. юрид. наук / 12.00.02. - Саратов, 2003.

20. Крусс В.И. Юбилей права: к вопросу о природе и назначении конституционной юстиции // Актуальные проблемы теории и практики конституционного судопроизводства: Сборник научных трудов. - Вып. VII. - Казань: ООО «Офсет-сервис», 2012. - C. 303-309.

21. Кряжков В.А., Лазарев Л.В. Конституционная юстиция в Российской Федерации. - М.: Изд-во «Бек», 1998.
22. Лукьянова Е.Г. Теория процессуального права. 2-е изд., перераб. - М.: Норма, 2004.

23. Марченко М.Н. Теория государства и права: Учебник. - М.: Проспект, 2003.

24. Мезинов Д.А. О соотношении понятий «цель» и «задача» в науке уголовного процесса // Вестник Томского государственного университета. - 2010. - № 340. - С. 129-131.

25. Несмеянова С.Э. Конституционный судебный процесс в России: Учебное пособие. - М.: РИОР; ИНФРА-М, 2012.

26. Новая философская энциклопедия: В 4 т. / Ин-т философии РАН; Нац. обществ.-науч. фонд; Предс. науч.-ред. совета акад. В.С. Степин. - М.: Мысль, 2000-2001. - URL: http://iph.ras.ru/elib/2902.html.

27. Общая теория государства и права: Академический курс: В 2 т. / Под ред. проф. Н.М. Марченко. Т. 2. Теория права. - М.: Зерцало, 1998.

28. Овсепян Ж.И. Конституционное судебно-процессуальное право: у истоков отрасли права, науки и учебной дисциплины // Известия вузов. Правоведение. - 1999. - № 2. - С. 196-201.

29. Полянский Н.Н. Очерки общей теории уголовного процесса. - М.: Право и Жизнь, 1927.

30. Правовые проблемы укрепления российской государственности: Сборник статей. Ч. 23 / Под ред. В.Ф. Воловича. - Томск: Изд-во Том. ун-та, 2005.

31. Процессуальное право: Энциклопедический словарь / Под ред. Т.Г. Морщаковой, П.А. Лупинской, Т.Е. Абовой, Н.Г. Салищевой. - М.: Норма, 2003.

32. Райкова Н.С. Сущность конституционного судопроизводства // Журнал конституционного правосудия. - 2008. - № 5. - С. 9-15.

33. Россинский Б.В. К вопросу о конституционном судебном процессе как разновидности юридического процесса в Российской Федерации // Российская юстиция. - 2012. - № 6. - С. 49-52.

34. Саликов М.С. Конституционный судебный процесс в системе российского права // Журнал российского права. - 2003. - № 11. - С. 120-128.

35. Свистунова Т.В. Нормы уголовно-процессуального права и правоотношения: Автореф. дис. ... канд. юрид. наук. - Л., 1969.

36. Слепченко Е.В. Конституционное судопроизводство: понятие и особенности // Юридический мир. -2009 . - № 2. - С. 17-23.

37. Соколов Т.В. К вопросу о сущности уголовного процесса в контексте доктрины судебного права // Российский судья. - 2013. - № 6. - С. 22-25. 
38. Теория государства и права: Курс лекций / Под ред. Н.И. Матузова и А.В. Малько. - М.: Юристь, 1997.

39. Теория государства и права: Учебник для юридических вузов / Под общ. ред. проф. А.С. Пиголкина. - М.: Городец, 2003.

40. Ткаченко Ю.Г. Методологические вопросы теории правоотношений: Монография. - М.: Юридическая литература, 1980.

41. Толстой Ю.К. К теории правоотношений: Монография. - Л.: Изд-во ЛГУ, 1959.

42. Федеральный закон от 31 мая 2001 года № 73Ф3 «О государственной судебно-экспертной деятельности в Российской Федерации» // Собрание законодательства Российской Федерации. - 2001. - № 23 (4 июня). - Ст. 2291.

43. Философский энциклопедический словарь. - М.: ИНФРА-М, 2009.

44. Халфина Р.О. Общее учение о правоотношении. М.: Юридическая литература, 1974.

45. Чеговадзе Л.А. Структура и состояние гражданского правоотношения: Монография. - М.: Статут, 2004.

46. С. И. Балабкин Об окончательности решений Конституционного суда Российской Федерации // Право и политика. - 2012. - 4. - С. 689-695.

47. Соколов Т.В. Решения и правовые позиции Конституционного Суда Российской Федерации: сущность, виды и соотношение // Право и политика. - 2013. - 12. - C. 1707-1719. DOI: 10.7256/18119018.2013.12.10169.

48. Кочетков В.В.. Русские ценности и российская Конституция 1993 года. // Право и политика. 2013. - № 13. - С. 1855-1865. DOI: .10.7256/18119018.2013.13.9736.

49. С.В. Нарутто. Конституционный судебный процесс: понятие, признаки, особенности. // Право и политика. - 2013. - № 5. - С. 708-713. DOI: $.10 .7256 / 1811-9018.2013 .05 .15$.

50. Д.В. Даниленко. Современная форма правления во Франции и конституционная реформа от 23 июля 2008 года.. // Право и политика. 2008. - № 12. - С. 2865-2870.

51. Г. Кельзен. Судебная гарантия Конституции (Конституционная юстиция. Часть 2. Окончание). // Право и политика. - 2006. - № 9.

52. Г. Кельзен. Судебная гарантия Конституции (Конституционная юстиция. Часть 1). // Право и политика. -2006. .№ 8.
53. Мильчакова О.В.. Конституционное правосудие на страже прав и свобод человека и гражданина. // Политика и Общество. -2013. -№ 12. -С. 15281536. DOI: .10.7256/1812-8696.2013.12.10446.

54. Добрынин Н.М.. В юбилей о проблемах взаимосвязи и взаимообусловленности Конституции России и конституционализма: природа, реальность, специфика, миф. // Право и политика. 2013. - № 13. - C. 1866-1881. DOI: .10.7256/18119018.2013.13.10181.

55. Каминская Н.В., Букач В.В., Билас И.Г.. Юридическое содержание конституционного права на обращение в контексте Конституции Российской Федерации и Конституции Украины. // Право и политика. - 2013. - № 13. - C. 1825-1830. DOI: .10.7256/1811-9018.2013.13.9817.

56. Савчин М.В.. Конституционно-конформное толкование законов и верховенство конституции. // Право и политика. - 2013. - № 13. - С. 1779-1785. DOI: .10.7256/1811-9018.2013.13.9690.

57. Е. Н. Данилова. Конституция РСФСР 1937 года: из истории подготовки, обсуждения и принятия. // Исторический журнал: научные исследования. - 2011. - № 4. - С. 99-109.

58. Е. Е. Жеребцова. К дискуссии о месте и роли решений Конституционного Суда Российской Федерации в системе источников российского конституционного права. // Право и политика. - 2010. - № 11.

\section{References (transliteration):}

1. Bozh'ev V.P. Ugolovno-protsessual'nye pravootnosheniya. - M.: Yuridicheskaya literatura, 1975.

2. Boikov A.D. K izucheniyu effektivnosti ugolovnoprotsessual'nogo zakona // Effektivnost' primeneniya ugolovnogo zakona. - M., 1973. - S. 150-164.

3. Vitruk N.V. Vidy proizvodstv v Konstitutsionnom Sude RF // Zhurnal konstitutsionnogo pravosudiya. 2009. - № 6 (12). - S. 11-17.

4. Vitruk N.V. Konstitutsionnoe pravosudie. Sudebnokonstitutsionnoe pravo i protsess: Uchebnoe posobie. - M.: Yurist', 2005.

5. Vitruk N.V. Proizvodstvo v Konstitutsionnom Sude RF po rassmotreniyu dela o sootvetstvii Konstitutsii RF initsiativy provedeniya referenduma RF po postanovlennomu voprosu (postanovlennym voprosam) referenduma // Zhurnal konstitutsionnogo pravosudiya. - 2010. - № 2 (14). - S. 10-12. 


\section{Политика и общество 2 (110) • 2014}

6. Vitruk N.V. Tsel', zadachi i funktsii konstitutsionnogo pravosudiya v gosudarstvakh novoi demokratii // Konstitutsionnoe pravosudie: Vestnik Konferentsii organov konstitutsionnogo kontrolya stran novoi demokratii. - 2002. - № 2 (16). - URL: www.concourt. am/armenian/con right/2.16-2002/vitruk.htm.

7. Vlasenko A.N. Sootnoshenie ponyatii: «sudebnaya vlast'», «sudebnaya deyatel'nost'», «pravosudie» i «sudoproizvodstvo» // Konstitutsionnye osnovy sudebnoi vlasti: Materialy Vserossiiskoi nauch. konf. (Moskva, Rossiiskaya akademiya pravosudiya, 23 oktyabrya 2003 g.) / Pod obshch. red. V.V. Ershova. - M.: Rossiiskaya akademiya pravosudiya, 2004. - S. 18-22.

8. Vlasenko N.A. O nomenklature spetsial'nostei nauchnykh rabotnikov v oblasti yurisprudentsii // Zhurnal rossiiskogo prava. - 2010. - № 7. - S. 98-109.

9. Vlasenko N.A., Vlasenko A.N. Sudebnaya vlast' i sudebnaya deyatel'nost' v Rossiiskoi Federatsii: Kratkii kurs lektsii. - M.: Rossiiskaya akademiya pravosudiya, 2005.

10. Gadzhiev G.A. Tseli, zadachi i prednaznachenie Konstitutsionnogo Suda Rossiiskoi Federatsii // Zhurnal konstitutsionnogo pravosudiya. - 2008. № 1. - S. 10-17; № 2. - S. 8-12.

11. Gol'msten A.Kh. Uchebnik russkogo grazhdanskogo sudoproizvodstva / Pod red. i s predisl. M.K. Treushnikova i Yu.A. Popovoi. - Krasnodar: Izd-vo KubGAU, 2004.

12. Gravina A.A., Kashepov V.P., Makarova O.A. Konstitutsionnye printsipy sudebnoi vlasti Rossiiskoi Federatsii: Monografiya / Otv. red. V.P. Kashepov. M.: Yurisprudentsiya, 2011.

13. Daguev A.V. Vidy proizvodstv i ikh osobennosti v konstitutsionnom sudoproizvodstve: Avtoref. dis. ... kand. yurid. nauk / 12.00.02.

14. Zhilin G.A. Konstitutsionnoe sudoproizvodstvo v mekhanizme sudebnoi zashchity prava // Zhurnal konstitutsionnogo pravosudiya. - 2011. - № 4 (22). - S. 2-3.

15. Kirillov V.I. Logika poznaniya sushchnosti: Monografiya. - M.: Vysshaya shkola, 1980.

16. Kornukova E.V. Konstitutsionnye osnovy pravosudiya po ugolovnym delam: Avtoref. dis. ... kand. yurid. nauk / 12.00.02. - Saratov, 2003.

17. Kruss V.I. Yubilei prava: k voprosu o prirode i naznachenii konstitutsionnoi yustitsii // Aktual'nye problemy teorii i praktiki konstitutsionnogo sudoproizvodstva: Sbornik nauchnykh trudov. - Vyp. VII. - Kazan’: OOO «Ofset-servis», 2012. - S. 303-309.
18. Kryazhkov V.A., Lazarev L.V. Konstitutsionnaya yustitsiya v Rossiiskoi Federatsii. - M.: Izd-vo «Bek», 1998.

19. Luk'yanova E.G. Teoriya protsessual'nogo prava. 2-e izd., pererab. - M.: Norma, 2004.

20. Marchenko M.N. Teoriya gosudarstva i prava: Uchebnik. - M.: Prospekt, 2003.

21. Mezinov D.A. O sootnoshenii ponyatii «tsel'» i «zadacha» $\mathrm{V}$ nauke ugolovnogo protsessa // Vestnik Tomskogo gosudarstvennogo universiteta. - 2010. № 340. - S. 129-131.

22. Nesmeyanova S.E. Konstitutsionnyi sudebnyi protsess v Rossii: Uchebnoe posobie. - M.: RIOR; INFRA-M, 2012.

23. Ovsepyan Zh.I. Konstitutsionnoe sudebnoprotsessual'noe pravo: u istokov otrasli prava, nauki i uchebnoi distsipliny // Izvestiya vuzov. Pravovedenie. - 1999. - № 2. - S. 196-201.

24. Polyanskii N.N. Ocherki obshchei teorii ugolovnogo protsessa. - M.: Pravo i Zhizn', 1927.

25. Raikova N.S. Sushchnost' konstitutsionnogo sudoproizvodstva // Zhurnal konstitutsionnogo pravosudiya. - 2008. - № 5. - S. 9-15.

26. Rossinskii B.V. K voprosu o konstitutsionnom sudebnom protsesse kak raznovidnosti yuridicheskogo protsessa v Rossiiskoi Federatsii // Rossiiskaya yustitsiya. - 2012. - № 6. - S. 49-52.

27. Salikov M.S. Konstitutsionnyi sudebnyi protsess v sisteme rossiiskogo prava // Zhurnal rossiiskogo prava. -2003 . - № 11. - S. 120-128.

28. Svistunova T.V. Normy ugolovno-protsessual'nogo prava i pravootnosheniya: Avtoref. dis. ... kand. yurid. nauk. - L., 1969.

29. Slepchenko E.V. Konstitutsionnoe sudoproizvodstvo: ponyatie i osobennosti // Yuridicheskii mir. 2009. - № 2. - S. 17-23.

30. Sokolov T.V. K voprosu o sushchnosti ugolovnogo protsessa $\mathrm{v}$ kontekste doktriny sudebnogo prava // Rossiiskii sud'ya. - 2013. - № 6. - S. 22-25.

31. Tkachenko Yu.G. Metodologicheskie voprosy teorii pravootnoshenii: Monografiya. - M.: Yuridicheskaya literatura, 1980.

32. Tolstoi Yu.K. K teorii pravootnoshenii: Monografiya. - L.: Izd-vo LGU, 1959.

33. Khalfina R.O. Obshchee uchenie o pravootnoshenii. - M.: Yuridicheskaya literatura, 1974.

34. Chegovadze L.A. Struktura i sostoyanie grazhdanskogo pravootnosheniya: Monografiya. - M.: Statut, 2004 
35. S. I. Balabkin Ob okonchatel'nosti reshenii Konstitutsionnogo suda Rossiiskoi Federatsii // Pravo i politika. - 2012. - 4. - C. 689-695.

36. Sokolov T.V. Resheniya i pravovye pozitsii Konstitutsionnogo Suda Rossiiskoi Federatsii: sushchnost', vidy i sootnoshenie // Pravo i politika. - 2013. - 12. - C. 1707-1719. DOI: 10.7256/18119018.2013.12.10169.

37. Kochetkov V.V.. Russkie tsennosti i rossiiskaya Konstitutsiya 1993 goda. // Pravo i politika. 2013. - № 13. - C. 1855-1865. DOI: .10.7256/18119018.2013.13.9736.

38. S.V. Narutto. Konstitutsionnyi sudebnyi protsess: ponyatie, priznaki, osobennosti. // Pravo i politika. - 2013. - № 5. - C. 708-713. DOI: .10.7256/18119018.2013.05.15.

39. D.V. Danilenko. Sovremennaya forma pravleniya vo Frantsii i konstitutsionnaya reforma ot 23 iyulya 2008 goda.. // Pravo i politika. - 2008. - № 12. - C. 2865-2870.

40. G. Kel'zen. Sudebnaya garantiya Konstitutsii (Konstitutsionnaya yustitsiya. Chast' 2. Okonchanie). // Pravo i politika. - 2006. - № 9.

41. G. Kel'zen. Sudebnaya garantiya Konstitutsii (Konstitutsionnaya yustitsiya. Chast' 1). // Pravo i politika. - 2006. - № 8 .
42. Mil'chakova O.V.. Konstitutsionnoe pravosudie na strazhe prav i svobod cheloveka i grazhdanina. // Politika i Obshchestvo. - 2013. - № 12. - C. 15281536. DOI: .10.7256/1812-8696.2013.12.10446.

43. Dobrynin N.M.. V yubilei o problemakh vzaimosvyazi i vzaimoobuslovlennosti Konstitutsii Rossii i konstitutsionalizma: priroda, real'nost', spetsifika, mif. // Pravo i politika. - 2013. - № 13. - C. 1866-1881. DOI: .10.7256/1811-9018.2013.13.10181.

44. Kaminskaya N.V., Bukach V.V., Bilas I.G.. Yuridicheskoe soderzhanie konstitutsionnogo prava na obrashchenie v kontekste Konstitutsii Rossiiskoi Federatsii i Konstitutsii Ukrainy. // Pravo i politika. - 2013. - № 13.C. 1825-1830. DOI: .10.7256/1811-9018.2013.13.9817.

45. Savchin M.V.. Konstitutsionno-konformnoe tolkovanie zakonov i verkhovenstvo konstitutsii. // Pravo i politika. - 2013. - № 13. - C. 1779-1785. DOI: $.10 .7256 / 1811-9018.2013 .13 .9690$.

46. E. N. Danilova. Konstitutsiya RSFSR 1937 goda: iz istorii podgotovki, obsuzhdeniya i prinyatiya. // Istoricheskii zhurnal: nauchnye issledovaniya. - 2011. - № 4. - C. 99-109.

47. E. E. Zherebtsova. K diskussii o meste i roli reshenii Konstitutsionnogo Suda Rossiiskoi Federatsii v sisteme istochnikov rossiiskogo konstitutsionnogo prava. // Pravo i politika. - 2010. - № 11. 